\title{
Assessment of Groundwater Quality for Drinking and Irrigation use in Kumadvati watershed, Karnataka, India
}

\author{
Lamphrang Laloo, G. Chandrakantha, Praveen G. Deshbhandari \\ Jnanasahyadri, Kuvempu University
}

\begin{abstract}
In the present study, groundwater samples were collected in the Kumadvati watershed, Karnataka State, India during the post-monsoon season of the year 2018 and pre-monsoon season of the year 2019 to know their suitability for domestic and agriculture activity. The water samples were analysed for $\mathrm{pH}, \mathrm{EC}$, TDS, TH and major cations and anions. Some of the samples during the postmonsoon season and pre-monsoon season are beyond the desirable limit and permissible limits for domestic use. Based on salinity, $39 \%$ of the groundwater is not suitable for irrigation. Piper plots indicate $\mathrm{Ca}^{2+}-\mathrm{Mg}^{2+}-\mathrm{HCO}_{3}{ }^{-}$is the dominant hydrogeochemical facies in the watershed. According to Hounslow, the groundwater of the study area belongs to a Type IV. According to the Wilcox diagram, in post-monsoon $97 \%$ fall in excellent to good and only $3 \%$ fall in the good to permissible zone. Whereas, in the pre-monsoon season, $61 \%$ fall in excellent to good, $39 \%$ in good to permissible zones. The Permeability index calculations also suggest that the groundwater is suitable for irrigation.
\end{abstract}

Keywords: Kumadvati, Domestic, Irrigation, water quality, hydrogeochemical facies

\section{INTRODUCTION}

Globally groundwater is important for domestics as well as for agriculture purposes due to uneven distribution of surface water resources. At present, due to population explosion, there is lots of stress on the quantity and quality of groundwater in developing countries including India. Monitoring of ground water quality is an effort to obtain information on chemical quality through representative sampling in different hydrogeological units (CGWB 2010). It is reported that the groundwater quality shows spatial variation in drinking and irrigation in India (Agrawal and Jagetia 1997; Subba Rao et al. 1999; Dasgupta and Purohit 2001; Khurshid et al. 2002; Sreedevi 2004; Subba Rao 2006; Gupta et al. 2008; Ali and Ali 2018). The hydrogeochemical study reveals the zones and quality of groundwater that is suitable for drinking, agricultural and industrial purposes (Anbazhagan and Archana 2004, Sadashivaiah et al. 2008). On the basis of water quality parameters, the natural groundwater of India has been categorized as desirable, permissible and unfit for human consumption (CGWB 2010). Further, it is possible to understand the change in quality due to rock-water interaction or any type of anthropogenic influence.

The groundwater quality depends on the geochemical process, mineralogical composition of aquifer material, residence time and the rate of groundwater flow through the different geological formations. Groundwater quality changes faster in weathered zones than in the un-weathered zones. In general, the groundwater is safer than surface water unless pollution due to anthropogenic activity. In recent times in many parts of India, the quality of groundwater has deteriorated to such an extent that some of the parameters are beyond the permissible limit. The shortage of good quality water resources across India in general and Karnataka state in particular, is an important issue. Hence, an attempt has been made to study the groundwater quality in Kumadvati watershed in Shivamogga district, Karnataka.

Location description:

The Kumadvati watershed a tributary of the Bhadra River lies between $14^{0} 08^{\prime} 00^{\prime \prime}$ and $13^{\circ} 46^{\prime} 00^{\prime \prime} \mathrm{N}$ latitude and $75^{\circ} 12$ '00' and $75^{\circ} 28^{\prime} 30^{\prime}$ 'E longitude (Fig 1). The watershed covers an area of $455 \mathrm{~km}^{2}$ and situated in Thirthhalli, Hosanagara, and Shivamogga taluks in Shimoga district. The elevation of the watershed varies from 522 to $955 \mathrm{~m}$ above the mean sea level. The maximum slope in the watershed is more than 35 degrees and the minimum slope is almost zero. The forest cover is about $56 \%$ of the total geographical area of the watershed. The annual average rainfall over the watershed is $1830 \mathrm{~mm}$. During the southwest monsoon, the watershed receives $83 \%$ of the annual rainfall and the remaining during the rest of the year. On average, there are 92 rainy days. The rainfall decreases from the southwest direction toward northeast directions of the watershed. The spatial variation in rainfall in the watershed is shown in Fig 2. 


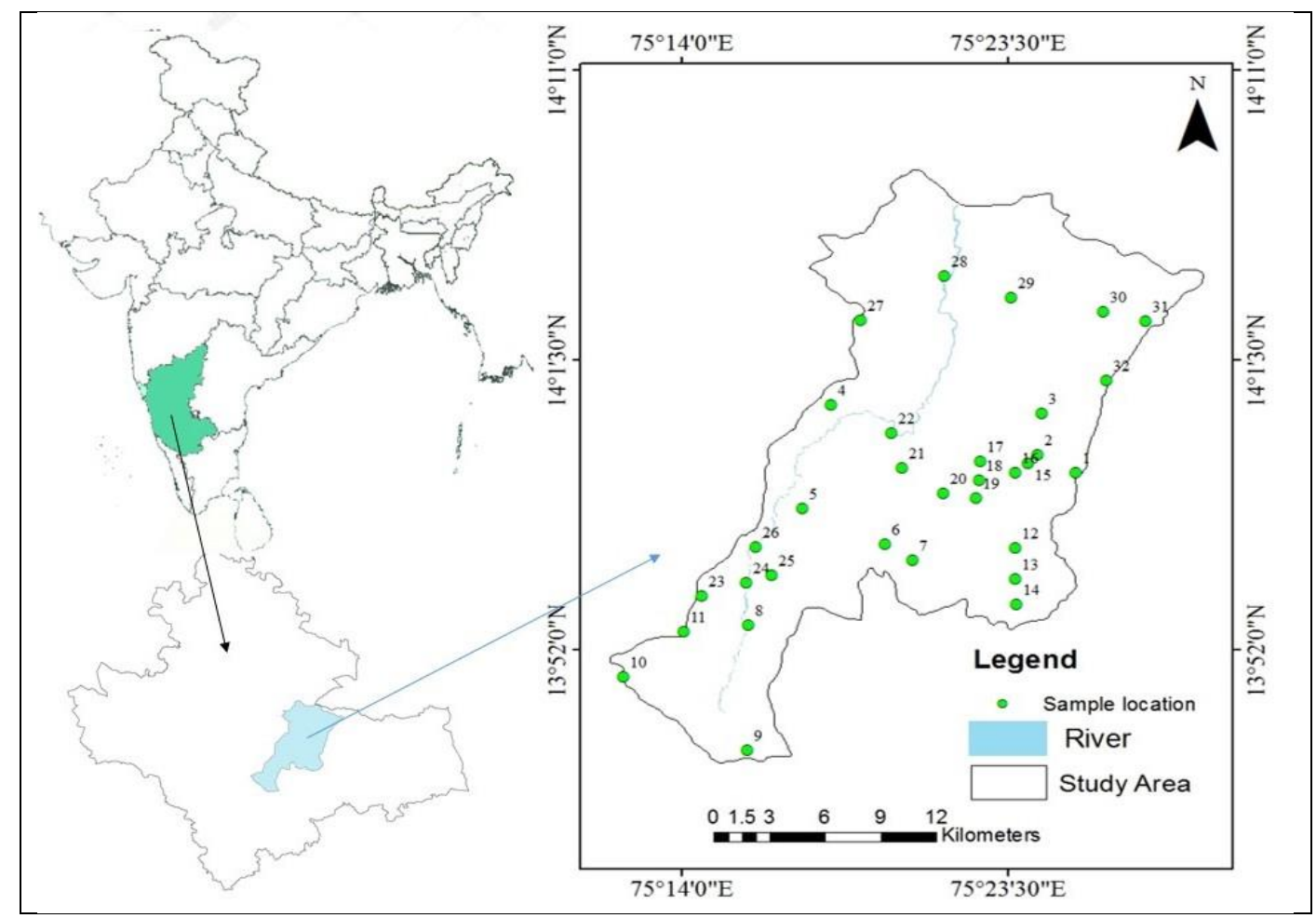

Fig 1: Location of the Study Area and groundwater sampling stations

Watershed is located in the Western Dharwar Craton (WDC) and the important rock formations belong to Achaean to Proterozoic age. The rocks are granite, gneisses, greywacke and quartz chlorite schist. These rocks are generally low in porosity and permeability. However, weathered, fracture and joints in these rocks serve as potential aquifers. The groundwater occurs under water table and semi-unconfined condition in the area.

\section{MATERIALS AND METHODS:}

Before identifying the water sample stations, the wells inventory survey is carried out and 32 wells were selected for groundwater sampling. These selected wells are spatially distributed within the watershed. For collecting a water sample, a prewashed one-liter polyethylene bottle was used. The bottle was rinsed with distilled water, followed by the well water before collection. The groundwater samples collected from bore wells and the location and altitude information about these wells were collected in the field using Garmin GPS.

The groundwater sample collected in the field was analysed for physical parameters like pH, EC, total dissolved solids (TDS). The $\mathrm{pH}$ and Electrical Conductivity (EC) were determined using Systronics-361pH meter and Systronics-306 Conductivity meter. By the gravimetric method, total dissolved solids (TDS) were estimated in the laboratory. The major cations like calcium, magnesium, sodium and potassium and anions such as bicarbonate, carbonate, chloride, nitrate, and sulfate were estimated in the laboratory by using standard methods given by the American public health association (APHA, 1995).The watershed boundary and the well location map are prepared in a GIS environment as polygon data and point data respectively. For spatial analysis, the point data table was updated by adding physical-chemical analysis data. 


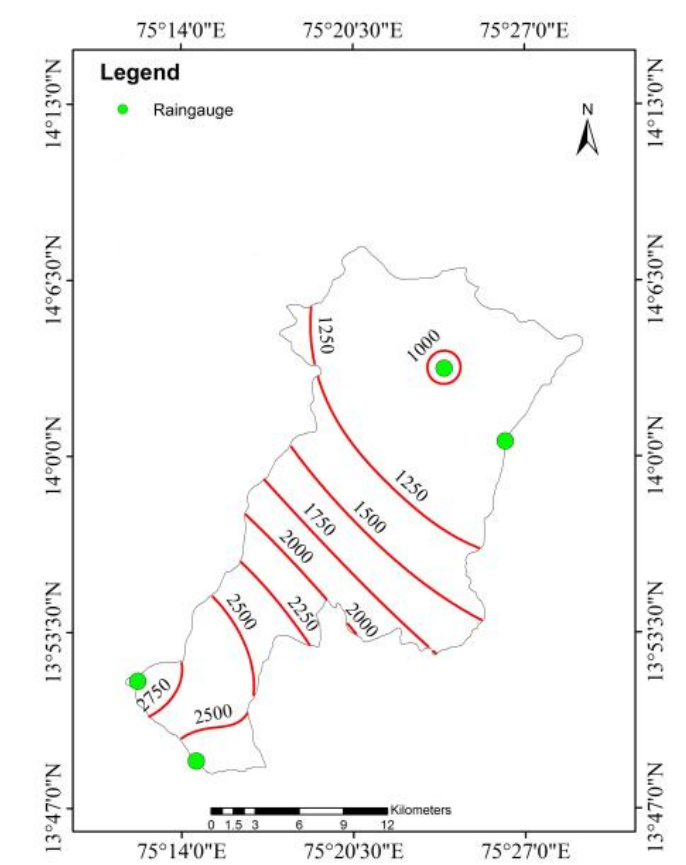

Fig 2: Spatial variation in Rainfall over the Kumadvati watershed

RESULTS AND DISCUSSIONS:

The Physico-chemical analysis results obtained from the groundwater samples of the post- and pre-monsoon seasons were tabulated in Table 1 and Table 2.

\section{Physical properties:}

The $\mathrm{pH}$ value during post- and pre-monsoon season range from 6.11 to 8.05 and 6.72 to 8.38 respectively. The average value during this period is 7.1 and 7.6. The groundwater samples are slightly alkaline during pre-monsoon season and are slightly acidic $(<6.5)$ during the post-monsoon season (Table 4). The decrease in $\mathrm{pH}$ value during the post-monsoon season is due to the interaction between soil and water (Subramanian et al., 1983).

The electrical conductivity (EC) of a water sample is a measure of the total dissolved solids, i.e. it depends upon the ionic strength of the solution. The measured EC value of the groundwater sample is in the range of 172 to 874 and 133 to $1350 \mu \mathrm{s} / \mathrm{cm}$ at $25^{\circ} \mathrm{C}$ during post and pre-monsoon seasons respectively. During this period, the average EC is 423 and $696 \mu \mathrm{s} / \mathrm{cm}$ respectively. According to Hem (1985), EC depends upon temperature, concentration, and types of ion present in water. The EC value of all water samples in the study area is less than $1500 \mu \mathrm{s} / \mathrm{cm}$ and they are classified as Type I, that is suitable for drinking purposes.

\section{TDS}

The water contains lots of organic and inorganic salt dissolved in it. These dissolved salts are essential for the overall growth of a human body. The total dissolved solids (TDS) up to a certain level are acceptable for human consumption. If the concentration of TDS exceeds the permissible limit, it becomes hazardous. The TDS in the groundwater samples in the watershed during the post- and pre-monsoon season is in the range from 110 to 560 and 85 to $865 \mathrm{mg} / \mathrm{l}$ respectively. The average value of TDS during the post- and pre-monsoon season is 272 and $445 \mathrm{mg} / \mathrm{l}$ respectively. According to Freeze and Cherry (1979), most of the groundwater in the watershed falls into the freshwater category. In one sample (sample No. 1) during the post-monsoon season and eleven samples $(1,2,5,6,8,10,11,28,29,30$ and 31) during the pre-monsoon season, the TDS is more than 500 mg/l. This indicates that TDS is well within the desirable limit during the post-monsoon season and within the permissible limit (2000 $\mathrm{mg} / \mathrm{l}$ ) during the pre-monsoon season (BIS, 2012).

\section{Total Hardness (TH)}

Hardness is primarily the amount of calcium and magnesium and to a lesser extent, iron in the water. In a natural environment, water hardness in most groundwater is due to weathering of calcium bearing mineral in rocks. Water hardness usually expressed as total hardness. It is caused by the presence of calcium and magnesium cations combine with carbonate, bicarbonate, chloride and sulphate anions in water. For domestic use, total hardness is an important property. The acceptable limit of total hardness as per the BIS norms is $300 \mathrm{mg} / \mathrm{l}$. In the absence of water with hardness less than $300 \mathrm{mg} / 1$, it may be extended up to $600 \mathrm{mg} / 1$.

The total hardness values in Kumadvati watershed during the post- and pre-monsoon seasons range from 50 to $870 \mathrm{mg} / \mathrm{l}$ and 25 to $2175 \mathrm{mg} / \mathrm{l}$ respectively. During this period, the average values are 214 and $304 \mathrm{mg} / \mathrm{l}$. According to BIS (2012) norms, $95 \%$ of the water samples are within the permissible limit of $600 \mathrm{mg} / \mathrm{l}$. According to Sawyer and MaCartly (1967), the groundwater of the Kumadvati watershed area is classified and is shown in Table 3.

During the post-monsoon season, $63 \%$ are moderately hard, $25 \%$ are hard and $12 \%$ are very hard. Similarly, in the pre-monsoon season, $35 \%$ are moderately hard, $52 \%$ are hard and $13 \%$ are very hard. Normally, the quality of groundwater deteriorates from post-monsoon season to pre-monsoon season because groundwater recharge does not take place due to no rainfall. In 
exceptional cases, groundwater quality improvement is observed in some of the wells during the pre-monsoon season. This may be due to the leaching of chemical fertilizer during the monsoon season. Hence, the quality of groundwater during the postmonsoon season has higher TH values.

\section{Bicarbonates $\left(\mathrm{HCO}_{3}^{-}\right)$}

\section{ANIONS:}

Bicarbonates in groundwater present in association with $\mathrm{Ca}^{2+}$ and $\mathrm{Mg}^{2+}$. In groundwater, bicarbonate mainly derived from the $\mathrm{CO}_{2}$ present in the soil above the water table. The $\mathrm{CO}_{2}$ combines with rainwater to form $\mathrm{HCO}_{3}^{-}$and $\mathrm{CO}_{3}\left(\mathrm{Stum}\right.$ and $\mathrm{Morgan}^{-}$ 1996). The bicarbonate content in the post-monsoon season range from 36.6 to $463.7 \mathrm{mg} / \mathrm{l}$ and the average value is $136.1 \mathrm{mg} / \mathrm{l}$. During the pre-monsoon season, it ranges from 67.1 to $610.2 \mathrm{mg} / \mathrm{l}$ and the average value is $199.6 \mathrm{mg} / \mathrm{l}$.

\section{Sulphate $\left(\mathrm{SO}_{4}{ }^{2+}\right)$}

Sulphur in groundwater is normally present in sulphate form. Sulphate may enter into groundwater through weathering of sulphide bearing rocks such as granite, fertilizer, and rainfall. The concentration of sulphate varies from 9 to $28 \mathrm{mg} / \mathrm{l}$ and 7.8 to $26 \mathrm{mg} / \mathrm{l}$ and the average values are $20.2 \mathrm{mg} / \mathrm{l}$ and $15 \mathrm{mg} / \mathrm{l}$ during the post-monsoon and pre-monsoon seasons respectively. Sulphate concentration in groundwater is within the permissible limit.

\section{Chloride $\left(\mathrm{Cl}^{-}\right)$}

Chloride in natural groundwater may be due to weathering or leaching of rock and seawater contamination. The concentration in groundwater samples in the study area during the post- and pre-monsoon season varies from 6 to $49.6 \mathrm{mg} / \mathrm{l}$ and 6 to $52 \mathrm{mg} / \mathrm{l}$ respectively. The average value during this period is $17.7 \mathrm{mg} / \mathrm{l}$ and $18.8 \mathrm{mg} / \mathrm{l}$. The water samples are within the permissible limit.

\section{Cations:}

\section{Calcium $\left(\mathrm{Ca}^{2+}\right)$}

Calcium is an important element for proper bone development in human beings (Ali and Ali 2018). It is very common in groundwater due to its abundance in most of the rocks. Its solubility in water is high compared to magnesium. In groundwater samples of Kumadvati watershed, the calcium content ranges from 12 to $222 \mathrm{mg} / \mathrm{l}$ and 4 to $220 \mathrm{mg} / \mathrm{l}$ during the post-monsoon and pre-monsoon seasons with an average value of $52.5 \mathrm{mg} / \mathrm{l}$ and $60.2 \mathrm{mg} / \mathrm{l}$ respectively. In most of the samples, the concentration of calcium is within the desirable limit $(75 \mathrm{mg} / \mathrm{l})$ except for a few samples that are within the permissible limit.

\section{Magnesium $\left(\mathbf{M g}^{2+}\right)$}

Similar to calcium, magnesium is also more abundant in groundwater; however, magnesium content is always less than calcium due to the slow solubility rate in groundwater. Magnesium ion is essential for the functioning of a cell in enzyme activation. Concentration higher than the permissible limits gives an unpleasant taste to water (Gar et al., 2009).

The magnesium content in the groundwater sample of the study area varies from 7 to $35 \mathrm{mg} / \mathrm{l}$ and 4 to $36 \mathrm{mg} / \mathrm{l}$ during postmonsoon and pre-monsoon seasons respectively, and average being $14.17 \mathrm{mg} / \mathrm{l}$ and $14.52 \mathrm{mg} / \mathrm{l}$ during the same period. In most of the samples, they are under desirable limit and wherever it exceeds the desirable limit, groundwater should be under control usage. 
Table 1: Physico-chemical parameters of groundwater samples of Kumadvati watershed during post-monsoon season

\begin{tabular}{|c|c|c|c|c|c|c|c|c|c|c|c|c|c|c|c|}
\hline \multirow{2}{*}{$\begin{array}{c}\text { Sample } \\
\text { No. }\end{array}$} & \multirow{2}{*}{$\mathrm{pH}$} & \multirow{2}{*}{$\begin{array}{c}\mathrm{EC} \\
(\mu \mathrm{s} / \mathrm{cm})\end{array}$} & $\mathrm{Ca}^{2+}$ & $\mathrm{Mg}^{2+}$ & $\mathrm{Na}^{+}$ & $\mathrm{K}^{+}$ & $\mathrm{HCO}_{3}^{-}$ & $\mathrm{SO}_{4}{ }^{2-}$ & $\mathrm{Cl}^{-}$ & $\mathrm{NO}_{3}{ }^{-}$ & TDS & $\mathrm{TH}$ & \multirow{2}{*}{ RSC } & \multirow{2}{*}{ SAR } & \multirow{2}{*}{$\% \mathrm{Na}$} \\
\hline & & & \multicolumn{10}{|c|}{ Values in $\mathrm{mg} / \mathrm{l}$} & & & \\
\hline 1 & 7.84 & 874 & 99 & 35 & 25 & 10 & 350 & 60 & 40 & 45 & 559 & 391 & -2.08 & 0.55 & 20.71 \\
\hline 2 & 7.8 & 697 & 40 & 10 & 6 & 3 & 128 & 14 & 16 & 19 & 446 & 141.15 & -0.72 & 0.22 & 15.25 \\
\hline 3 & 7.86 & 545 & 60 & 25 & 45 & 4.7 & 250 & 50 & 49.6 & 40 & 349 & 252.5 & -0.95 & 1.23 & 36.90 \\
\hline 4 & 7.83 & 517 & 65 & 30 & 25 & 8 & 280 & 58 & 20 & 35 & 331 & 285.5 & -1.12 & 0.65 & 25.78 \\
\hline 5 & 7.91 & 289 & 70 & 33 & 24 & 9 & 300 & 50 & 25 & 38 & 185 & 310.5 & -1.29 & 0.59 & 24.26 \\
\hline 6 & 7.9 & 427 & 76 & 28 & 20 & 8 & 301 & 35 & 27 & 35 & 273 & 304.5 & -1.16 & 0.50 & 21.21 \\
\hline 7 & 7.76 & 314 & 39 & 10 & 5 & 2 & 130 & 12 & 15 & 18 & 201 & 139.15 & -0.65 & 0.18 & 12.50 \\
\hline 8 & 7.96 & 310 & 25 & 16 & 9 & 2.4 & 133 & 9 & 13 & 16 & 198 & 128.5 & -0.39 & 0.34 & 21.76 \\
\hline 9 & 7.8 & 178 & 44 & 11 & 6 & 1 & 151 & 11 & 15 & 20 & 114 & 155.25 & -0.63 & 0.21 & 11.29 \\
\hline 10 & 8.03 & 422 & 39 & 9 & 8 & 2.3 & 156 & 10 & 6 & 17 & 270 & 134.55 & -0.13 & 0.30 & 17.67 \\
\hline 11 & 8.05 & 459 & 35 & 11 & 9 & 4 & 145 & 10 & 6 & 25 & 294 & 132.25 & -0.27 & 0.34 & 22.03 \\
\hline 12 & 6.71 & 426 & 38 & 10 & 9 & 2 & 135 & 11 & 6 & 34 & 273 & 136.15 & -0.51 & 0.34 & 18.64 \\
\hline 13 & 6.82 & 336 & 42 & 14 & 9 & 2.1 & 155 & 4 & 21 & 35 & 215 & 162.5 & -0.71 & 0.31 & 16.54 \\
\hline 14 & 6.48 & 584 & 46 & 14 & 6 & 1.2 & 146 & 4 & 19 & 37 & 374 & 172.5 & -1.06 & 0.20 & 10.71 \\
\hline 15 & 7.11 & 560 & 55 & 11 & 4 & 1.5 & 179 & 2 & 15 & 35 & 358 & 182.25 & -0.72 & 0.13 & 7.69 \\
\hline 16 & 7.26 & 484 & 42 & 9 & 2 & 1.1 & 109 & 14 & 19 & 27 & 310 & 142.05 & -1.05 & 0.07 & 5.73 \\
\hline 17 & 6.58 & 683 & 33 & 16 & 3 & 1.3 & 109 & 14 & 19 & 27 & 437 & 148.5 & -1.18 & 0.11 & 8.07 \\
\hline 18 & 6.5 & 454 & 37 & 12 & 1.9 & 1 & 95.5 & 19 & 21 & 24 & 290 & 141.9 & -1.27 & 0.07 & 5.59 \\
\hline 19 & 6.77 & 264 & 44.3 & 11.1 & 1.5 & 0.9 & 130.4 & 9.1 & 19 & 21 & 169 & 156.2 & -0.98 & 0.05 & 4.15 \\
\hline 20 & 6.56 & 172 & 34 & 9 & 1.1 & 0.6 & 96 & 6 & 16 & 22 & 110 & 122.05 & -0.87 & 0.04 & 3.80 \\
\hline 21 & 6.71 & 384 & 29 & 9 & 1 & 0.4 & 86 & 3 & 15 & 21 & 246 & 109.55 & -0.78 & 0.04 & 3.55 \\
\hline 22 & 6.82 & 320 & 26 & 8 & 1.2 & 0.6 & 76 & 2.1 & 15 & 19 & 205 & 97.9 & -0.71 & 0.05 & 5.03 \\
\hline 23 & 7.05 & 192 & 26.6 & 7.29 & 2.6 & 1.1 & 79 & 2.5 & 14.9 & 18.5 & 123 & 96.5 & -0.63 & 0.12 & 9.84 \\
\hline 24 & 6.11 & 484 & 42.3 & 10 & 2.9 & 1.4 & 97 & 21 & 17 & 36 & 310 & 146.15 & -1.33 & 0.10 & 7.60 \\
\hline 25 & 6.18 & 626 & 40 & 9.2 & 4 & 2.1 & 99 & 21 & 19 & 30 & 399 & 137.85 & -1.14 & 0.15 & 11.03 \\
\hline 26 & 6.48 & 344 & 41 & 14 & 5.1 & 2.3 & 155 & 16 & 12 & 22 & 220 & 160 & -0.66 & 0.17 & 11.86 \\
\hline 27 & 6.77 & 538 & 35 & 10 & 6 & 2 & 121 & 12 & 7 & 28 & 344 & 128.65 & -0.59 & 0.23 & 15.09 \\
\hline 28 & 7.11 & 468 & 37 & 7 & 4 & 1 & 110 & 10 & 9 & 22 & 299 & 121.3 & -0.63 & 0.16 & 10.20 \\
\hline 29 & 6.82 & 438 & 40 & 9 & 4.5 & 1.6 & 120 & 14 & 13 & 21 & 280 & 137.05 & -0.77 & 0.17 & 11.07 \\
\hline 30 & 6.91 & 326 & 34 & 10 & 4 & 2 & 118 & 12 & 9 & 19 & 209 & 126.15 & -0.59 & 0.15 & 12.00 \\
\hline 31 & 6.82 & 190 & 30 & 8 & 3 & 0.6 & 99 & 9 & 6 & 20 & 122 & 107.9 & -0.54 & 0.13 & 8.65 \\
\hline 32 & 6.9 & 228 & 91 & 28 & 19 & 5 & 321 & 29 & 42 & 32 & 184 & 342 & -1.58 & 0.45 & 16.78 \\
\hline
\end{tabular}

Table 2: Physico-chemical parameters of groundwater samples of Kumadvati watershed during pre-monsoon season

\begin{tabular}{|c|c|c|c|c|c|c|c|c|c|c|c|c|c|c|c|}
\hline \multirow{2}{*}{$\begin{array}{c}\text { Sample } \\
\text { No. }\end{array}$} & \multirow{2}{*}{$\mathrm{pH}$} & \multirow{2}{*}{$\begin{array}{c}\mathrm{EC} \\
(\mu \mathrm{s} / \mathrm{cm}) \\
\end{array}$} & $\mathrm{Ca}^{2+}$ & $\mathrm{Mg}^{2+}$ & $\mathrm{Na}^{+}$ & $\mathrm{K}^{+}$ & $\mathrm{HCO}_{3}{ }^{-}$ & $\mathrm{SO}_{4}{ }^{2+}$ & $\mathrm{Cl}^{-}$ & $\mathrm{NO}_{3}{ }^{-}$ & TDS & $\mathrm{TH}$ & \multirow{2}{*}{ RSC } & \multirow{2}{*}{ SAR } & \multirow{2}{*}{$\% \mathrm{Na}$} \\
\hline & & & \multicolumn{10}{|c|}{ Values in mg/l } & & & \\
\hline 1 & 7.7 & 1000 & 45 & 10 & 8 & 4.2 & 135 & 16 & 19 & 21 & 640 & 153.65 & -0.86 & 0.28 & 18.15 \\
\hline 2 & 7.6 & 955 & 42 & 13 & 4 & 3.5 & 140 & 14 & 16 & 19 & 611 & 158.5 & -0.87 & 0.14 & 12.00 \\
\hline 3 & 7.24 & 527 & 28 & 15 & 6 & 4 & 131 & 9 & 13 & 19 & 337 & 131.5 & -0.48 & 0.23 & 18.87 \\
\hline 4 & 8 & 691 & 49 & 13 & 5 & 3 & 159 & 13 & 16 & 22 & 442 & 176 & -0.91 & 0.16 & 11.43 \\
\hline 5 & 7.35 & 870 & 101 & 36 & 26 & 8 & 370 & 63 & 42 & 39 & 557 & 400 & -1.93 & 0.57 & 19.88 \\
\hline 6 & 8.07 & 890 & 45 & 12 & 6 & 1.9 & 161 & 14 & 9 & 21 & 569 & 161.9 & -0.60 & 0.21 & 12.17 \\
\hline 7 & 7.8 & 590 & 70 & 28 & 48 & 6 & 280 & 55 & 52 & 35 & 377 & 289.5 & -1.20 & 1.23 & 35.53 \\
\hline 8 & 7.86 & 808 & 40 & 14 & 7 & 3.2 & 158 & 12 & 8 & 27 & 517 & 157.5 & -0.56 & 0.24 & 15.89 \\
\hline 9 & 8.3 & 778 & 42 & 12 & 6 & 1.5 & 147 & 13 & 7 & 31 & 498 & 154.4 & -0.68 & 0.21 & 12.20 \\
\hline 10 & 7.74 & 814 & 40 & 16 & 8 & 3 & 164 & 10 & 9 & 29 & 521 & 166 & -0.63 & 0.27 & 16.42 \\
\hline 11 & 7.4 & 823 & 42 & 12 & 5 & 2 & 140 & 5 & 18 & 32 & 527 & 154.4 & -0.79 & 0.17 & 11.48 \\
\hline 12 & 8.3 & 738 & 50 & 10 & 6 & 3 & 160 & 7 & 19 & 29 & 472 & 166.15 & -0.70 & 0.20 & 13.04 \\
\hline 13 & 8.12 & 732 & 76 & 28 & 25 & 7 & 291 & 61 & 25 & 29 & 468 & 304.5 & -1.32 & 0.62 & 23.53 \\
\hline 14 & 7.78 & 703 & 39 & 8 & 3 & 1.9 & 104 & 10 & 17 & 24 & 450 & 130.4 & -0.91 & 0.11 & 9.44 \\
\hline 15 & 7.8 & 376 & 30 & 13 & 4 & 2.1 & 105.5 & 12 & 15 & 24.4 & 241 & 128.5 & -0.84 & 0.15 & 12.42 \\
\hline 16 & 7.04 & 220 & 39 & 14 & 1.3 & 3 & 110 & 21 & 19 & 21 & 141 & 155 & -1.30 & 0.05 & 7.50 \\
\hline 17 & 6.75 & 485 & 63 & 24 & 22 & 4 & 256 & 51 & 19 & 21 & 310 & 256 & -0.78 & 0.60 & 23.01 \\
\hline 18 & 7.27 & 457 & 49 & 13 & 2.3 & 2 & 140 & 12.3 & 21 & 24 & 292 & 176 & -1.22 & 0.08 & 6.49 \\
\hline 19 & 7.38 & 441 & 70 & 22 & 19 & 6 & 280 & 33 & 29 & 26 & 282 & 265 & -0.71 & 0.51 & 21.37 \\
\hline 20 & 8.02 & 561 & 85 & 26 & 17 & 4 & 295 & 31 & 36 & 30 & 359 & 319 & -1.54 & 0.41 & 15.91 \\
\hline 21 & 7.79 & 681 & 36 & 11 & 2.1 & 0.9 & 109 & 7 & 19 & 21 & 436 & 135.25 & -0.92 & 0.08 & 6.00 \\
\hline 22 & 7.61 & 286 & 30 & 11 & 1.6 & 1.1 & 94 & 5 & 17 & 23 & 183 & 120.25 & -0.87 & 0.06 & 6.18 \\
\hline 23 & 8.38 & 555 & 29 & 10 & 1 & 0.4 & 82 & 6 & 18 & 22 & 355 & 114.15 & -0.94 & 0.04 & 3.47 \\
\hline 24 & 6.8 & 133 & 22 & 10 & 2.6 & 1.9 & 91 & 4 & 6 & 21 & 85.1 & 96.15 & -0.43 & 0.12 & 12.33 \\
\hline 25 & 8.19 & 480 & 44 & 12 & 2.4 & 2 & 110 & 19 & 22 & 30 & 307 & 159.4 & -1.39 & 0.08 & 7.28 \\
\hline 26 & 7.05 & 498 & 46 & 11 & 5 & 3 & 120 & 15 & 23 & 28 & 319 & 160.25 & -1.24 & 0.17 & 12.31 \\
\hline 27 & 6.72 & 525 & 44 & 15 & 7 & 2.9 & 160 & 17 & 15 & 26 & 336 & 171.5 & -0.81 & 0.23 & 14.37 \\
\hline 28 & 7.55 & 1060 & 40 & 12 & 5 & 4 & 130 & 14 & 10 & 30 & 678 & 149.4 & -0.86 & 0.18 & 14.75 \\
\hline 29 & 7.68 & 1260 & 42 & 9 & 6 & 2 & 125 & 13 & 11 & 25 & 806 & 140.7 & -0.76 & 0.22 & 13.56 \\
\hline 30 & 7.82 & 1300 & 51 & 4 & 6 & 2.5 & 130 & 15 & 11 & 29 & 832 & 143.45 & -0.74 & 0.22 & 13.39 \\
\hline 31 & 7.36 & 1350 & 55 & 6 & 8 & 4 & 145 & 17 & 22 & 27 & 864 & 161.7 & -0.85 & 0.27 & 16.44 \\
\hline
\end{tabular}


Table 3: Groundwater Classification based on Total Hardness (Sawyer and MaCartly 1967)

\begin{tabular}{|c|c|c|c|c|c|}
\hline \multirow{2}{*}{ Total hardness as $\mathrm{CaCO}_{3}(\mathrm{mg} / \mathrm{l})$} & \multirow{2}{*}{ Water class } & \multicolumn{4}{|c|}{ Sample numbers } \\
\hline & & Post-monsoon & $\%$ & Pre-monsoon & $\%$ \\
\hline$<75$ & Soft & Nil & - & Nil & - \\
\hline $75-150$ & Moderately hard & $2,7,8,10-12,16-18,20-25,27-31$ & 63 & $3,14,15,21-24,28-31$ & 35 \\
\hline $150-300$ & Hard & $3,4,9,13,14,15,19,26$ & 25 & $1,2,4,6-12,16-19,25-27$ & 52 \\
\hline$>300$ & Very hard & $1,5,6,32$ & 12 & $5,13,14,20$ & 13 \\
\hline
\end{tabular}

\section{Nitrate $\left(\mathrm{NO}_{3}{ }^{-}\right)$}

All nitrate salts are soluble in water and easily lost by leaching. Higher nitrate concentration in drinking water can be harmful to human beings. Nitrate in water is converted to nitrite by bacteria in the digestive system and then absorbed into the blood where they convert haemoglob into methaemoglobin (Hart, 1974), thus decreasing the oxygen-carrying capacity of the blood. The high concentration of Nitrate in groundwater is due to drainage of water through the soil, which has been repeatedly applied fertilizer. Nitrate in groundwater sample in the watershed is found to vary from 16 to 45 and 19 to 39 mg/l during the post- and pre-monsoon season respectively. Comparatively, $\mathrm{NO}_{3}{ }^{-}$is high in groundwater during the post-monsoon season is due to excess fertilizer applied to fields in monsoon season.

The range of the Physico-chemical parameter of groundwater samples of the pre-monsoon and post-monsoon in Kumadvati watershed is compared with the drinking water standards of BIS (2012) and is shown in Table 4.The statistical parameters like minimum and maximum, mean, standard deviation of the groundwater quality parameters are given in Table 5. Spatial distribution maps are prepared for the watershed using Arc GIS 10.2 software by IDW interpolation techniques. Spatial variation in $\mathrm{pH}, \mathrm{EC}$ and total hardness of groundwater in the Kumadvati watershed during post-monsoon and pre-monsoon is shown in Fig 3.
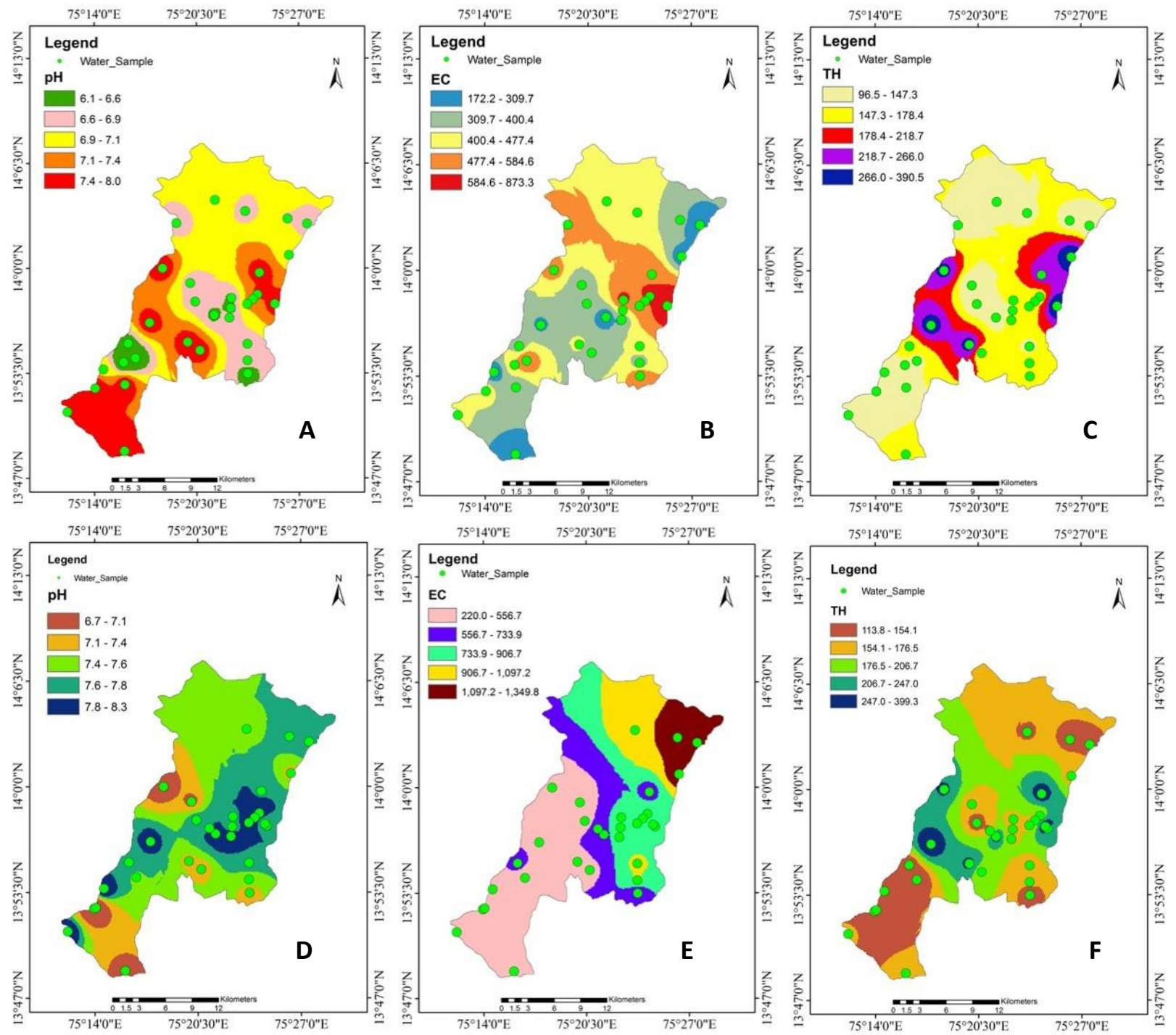

Fig 3: Spatial variation of $\mathrm{pH}, \mathrm{EC}$ and $\mathrm{TH}$ during post-monsoon (A, B, and C) and pre-monsoon period (D, E and F) 
Table 4: Comparison of Analytical Data with BIS (2012) for domestic use

\begin{tabular}{|c|c|c|c|c|c|c|c|c|}
\hline \multirow[b]{2}{*}{ Parameter } & \multicolumn{2}{|c|}{ Range } & \multicolumn{2}{|c|}{ Average } & \multicolumn{2}{|c|}{ BIS Limit (2012) } & \multicolumn{2}{|c|}{ Sample number } \\
\hline & $\begin{array}{c}\text { Post- } \\
\text { monsoon }\end{array}$ & Pre-monsoon & $\begin{array}{c}\text { Post- } \\
\text { monsoon }\end{array}$ & Pre-monsoon & Desirable & Permissible & Post-monsoon & Pre-monsoon \\
\hline $\mathrm{pH}$ & $6.11-8.05$ & $6.72-8.38$ & 7.1 & 7.6 & $6.5-8.5$ & $8.5-9.2$ & $24,25,26$ & - \\
\hline $\mathrm{EC}(\mu \mathrm{S} / \mathrm{cm})$ & $172-874$ & $133-1350$ & 422.9 & 696.4 & & & - & - \\
\hline TDS(mg/l) & $110-559$ & $85.1-864$ & 271.8 & 445.5 & 500 & 2000 & - & - \\
\hline TH (mg/l ) & $96.5-391$ & $96.1-400$ & 170.31 & 179.23 & 200 & 600 & - & - \\
\hline $\mathrm{Ca}^{2+}(\mathrm{mg} / \mathrm{l})$ & 25-99 & 22-101 & 44.85 & 47.87 & 75 & 200 & - & - \\
\hline $\mathrm{Mg}^{2+}(\mathrm{mg} / \mathrm{l})$ & $7-35$ & $4-36$ & 14.17 & 14.52 & 30 & 100 & - & - \\
\hline $\mathrm{Cl}^{-}(\mathrm{mg} / \mathrm{l})$ & $6-49.6$ & $6-52$ & 17.70 & 18.81 & 250 & 1000 & - & - \\
\hline $\mathrm{HCO}_{3}^{-} .(\mathrm{mg} / \mathrm{l})$ & $76-350$ & $82-370$ & 155.00 & 162.02 & & & - & - \\
\hline $\mathrm{Na}^{+}(\mathrm{mg} / \mathrm{l})$ & $1-45$ & $1-48$ & 8.65 & 8.88 & & & - & - \\
\hline $\mathrm{K}^{+}(\mathrm{mg} / \mathrm{l})$ & $0.4-10$ & $0.4-8$ & 2.69 & 3.16 & & & - & - \\
\hline $\mathrm{SO}_{4}{ }^{2+}(\mathrm{mg} / \mathrm{l})$ & $2-60$ & $4-63$ & 17.30 & 19.17 & 200 & 400 & - & - \\
\hline
\end{tabular}

Table 5: Statistical Parameters of Hydrochemical parameters of Kumadvati watershed during the post- and pre-monsoon

\begin{tabular}{|c|c|c|c|c|c|c|c|c|c|c|}
\hline \multirow[b]{2}{*}{ Parameter } & Min & & Max & $\mathrm{m}$ & ons & & $\mathrm{Me}$ & & \multicolumn{2}{|c|}{$\mathrm{SD}$} \\
\hline & $\begin{array}{l}\text { Post } \\
\text { Mon } \\
\end{array}$ & $\begin{array}{l}\text { Pre } \\
\text { Mon }\end{array}$ & $\begin{array}{l}\text { Post } \\
\text { Mon } \\
\end{array}$ & $\begin{array}{c}\text { Pre } \\
\text { Mon }\end{array}$ & $\begin{array}{l}\text { Post } \\
\text { Mon } \\
\end{array}$ & $\begin{array}{l}\text { Pre } \\
\text { Mon }\end{array}$ & $\begin{array}{l}\text { Post } \\
\text { Mon }\end{array}$ & $\begin{array}{c}\text { Pre } \\
\text { Mon }\end{array}$ & $\begin{array}{l}\text { Post } \\
\text { Mon }\end{array}$ & $\begin{array}{c}\text { Pre } \\
\text { Mon }\end{array}$ \\
\hline $\mathrm{pH}$ & 6.11 & 6.72 & 8.05 & 8.38 & 7.13 & 7.63 & 6.905 & 7.7 & 0.60 & 0.46 \\
\hline $\mathrm{EC}(\mu \mathrm{s} / \mathrm{cm})$ & 172 & 133 & 874 & 1350 & 422.91 & 696.35 & 426.5 & 691 & 165.86 & 299.83 \\
\hline TDS (mg/l) & 110 & 85.1 & 559 & 864 & 271.78 & 445.55 & 273 & 442 & 104.78 & 191.86 \\
\hline $\mathrm{TH}(\mathrm{mg} / \mathrm{l})$ & 96.5 & 96.15 & 391 & 400 & 170.31 & 179.23 & 141.525 & 158.5 & 75.26 & 68.80 \\
\hline $\mathrm{Ca}^{2+}(\mathrm{mg} / \mathrm{l})$ & 25 & 22 & 99 & 101 & 44.85 & 47.87 & 40 & 44 & 17.85 & 17.32 \\
\hline $\mathrm{Mg}^{2+}(\mathrm{mg} / \mathrm{l})$ & 7 & 4 & 35 & 36 & 14.17 & 14.52 & 10.5 & 12 & 8.09 & 7.12 \\
\hline $\mathrm{Na}^{+}(\mathrm{mg} / \mathrm{l})$ & 1 & 1 & 45 & 48 & 8.65 & 8.88 & 5.05 & 6 & 9.72 & 9.95 \\
\hline $\mathrm{K}^{+}(\mathrm{mg} / \mathrm{l})$ & 0.4 & 0.4 & 10 & 8 & 2.69 & 3.16 & 2 & 3 & 2.59 & 1.74 \\
\hline $\mathrm{HCO}_{3}^{-}(\mathrm{mg} / \mathrm{l})$ & 76 & 82 & 350 & 370 & 155.00 & 162.02 & 130.2 & 140 & 76.12 & 71.65 \\
\hline $\mathrm{SO}_{4}{ }^{2-}(\mathrm{mg} / \mathrm{l})$ & 2 & 4 & 60 & 63 & 17.30 & 19.17 & 12 & 14 & 16.11 & 16.41 \\
\hline $\mathrm{Cl}^{-}(\mathrm{mg} / \mathrm{l})$ & 6 & 6 & 49.6 & 52 & 17.70 & 18.81 & 15.5 & 18 & 10.19 & 10.03 \\
\hline $\mathrm{NO}_{3}^{-}(\mathrm{mg} / \mathrm{l})$ & 16 & 19 & 45 & 39 & 26.83 & 25.98 & 24.5 & 26 & 8.02 & 4.84 \\
\hline $\mathrm{RSC}$ & -2.08 & 0.04 & -0.13 & 1.23 & -0.87 & 0.26 & -0.75 & 0.21 & 0.39 & 0.24 \\
\hline SAR & 0.04 & -1.93 & 1.23 & -0.43 & 0.26 & -0.92 & 0.18 & -0.86 & 0.24 & 0.33 \\
\hline $\mathrm{Na} \%$ & 3.55 & 3.47 & 36.90 & 35.53 & 13.53 & 14.09 & 11.57 & 13.04 & 7.59 & 6.37 \\
\hline
\end{tabular}

According to Gibbs (1970), a close relationship exists between water chemistry and aquifer lithology. To know the relationship, Gibbs plots were prepared by plotting ratios of dominant anions $\left(\mathrm{Na}^{+}+\mathrm{K}^{+}\right) /\left(\mathrm{Na}^{+}+\mathrm{K}^{+}+\mathrm{Ca}^{2+}\right) \mathrm{Vs}$. TDS and $\mathrm{Cl}^{-} / \mathrm{Cl}^{-}+\mathrm{HCO}_{3}^{-} \mathrm{Vs}^{-}$ TDS(Fig 4). It is found that groundwater samples during the post- and pre-monsoon are due to rock and water interaction (Gibbs 1970).
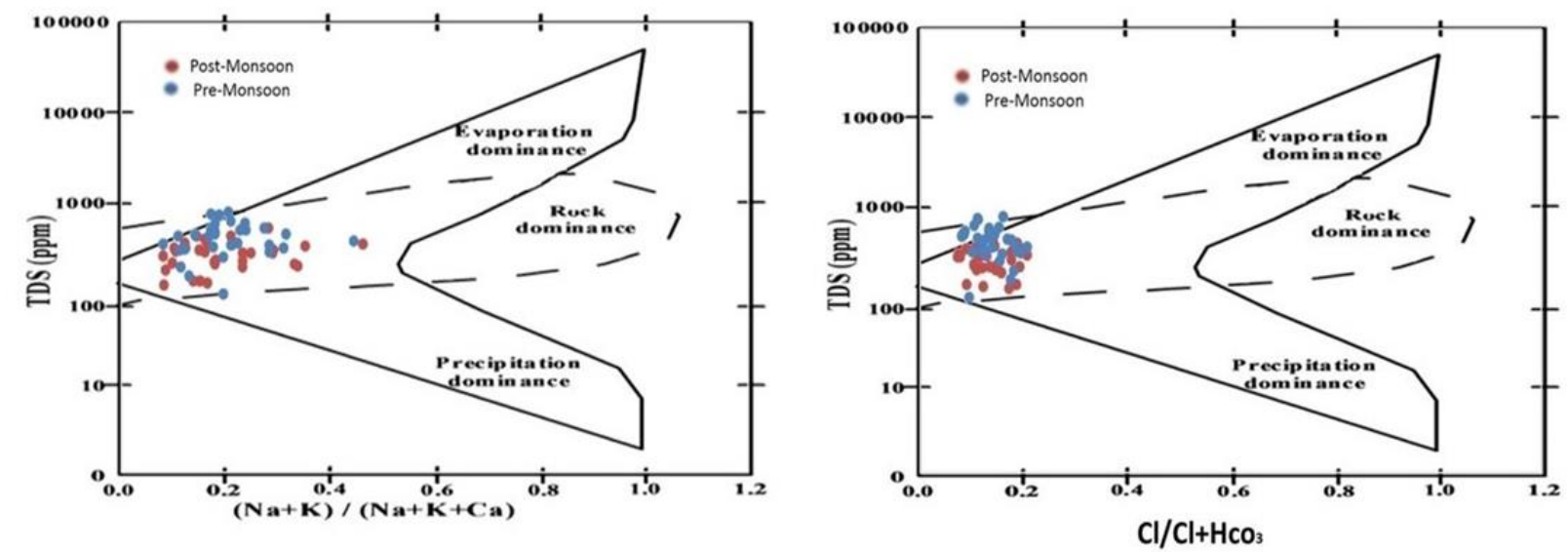

Fig 4: Mechanism controlling groundwater chemistry in Kumadvati watershed

To know the relationship between anions and cations in the Kumadvati watershed scatter diagram was prepared. The total anions vs. total cations show a linear relationship with a correlation coefficient of $\mathrm{R}=0.99$ (Fig 5). 


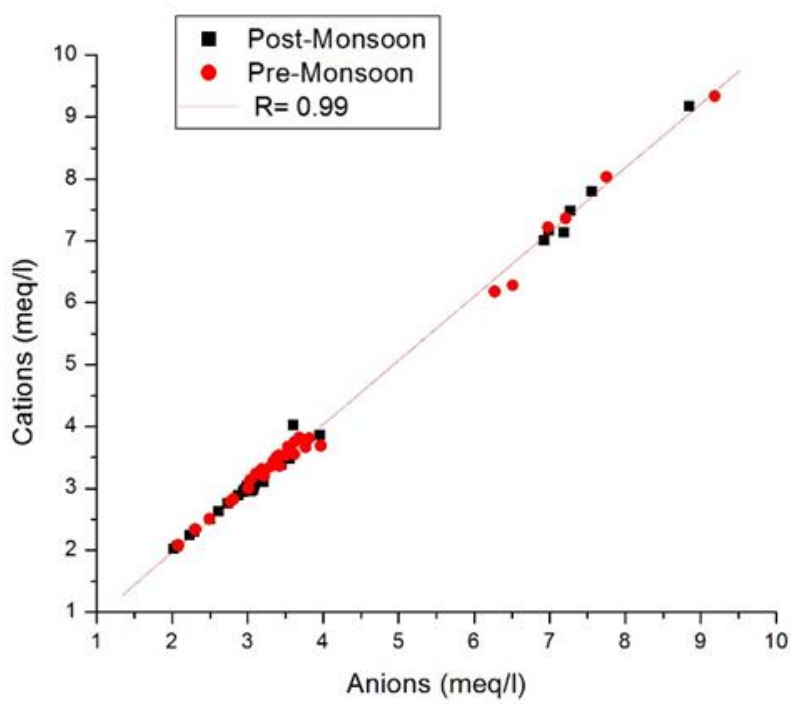

Fig 5: Scatter diagram between Anions Vs Cations

\section{Groundwater suitability for irrigation}

Agriculture irrigation is the major consumption of water in India. Mineral constituents in water used for irrigation are very essential for plant growth as well in agricultural yield. Suitability of water for irrigation depends on types of ions present and their concentration. The highest concentration of some of the ions is harmful to plant growth. Hence, groundwater in the watershed is analysed for the various parameters to know their suitability or not. Water quality parameters such as a Sodium Adsorption Ratio (SAR), Percent Sodium (\%Na), Residual Sodium Carbonate (RSC), Permeability Index (PI) and Magnesium Hazard $(\mathrm{MH})$ are determined based on various ions in groundwater samples expressed in meq/l.

\section{Sodium Adsorption Ratio (SAR)}

The major portion associated with sodium in irrigation water is related to the possible adverse effect on soil structure and permeability caused by the accumulation of sodium ions in the soil. The magnitude of the effect can be related to the relative proportion of sodium ions and calcium, plus magnesium ions in the irrigation water. The crop tolerance to alkali/sodium hazard is estimated by the following formula suggested by Richards (1954).

$$
\mathrm{SAR}=\frac{N a}{\sqrt{\frac{C a+M g}{2}}}
$$

The calculated SAR values of irrigation water in the watershed during post- and pre-monsoon season are in the range of 0.04 to 1.23 and -1.93 to -0.43 respectively (Table 5). They are low sodium water, which indicate little danger of sodium. Since calcium is the predominant adsorbed cation in both seasons, soil tend to have a granular structure, which is easily worked and readily permeable.

\section{Percentage Sodium (\% Na)}

According to Wilcox (1955), in irrigation water, the percentage of sodium content assessment is essential for its suitability for agricultural purposes. If the concentration of sodium ion is high in irrigation water, $\mathrm{Na}^{+}$tends to be adsorbed by the clay particles, will displace $\mathrm{Mg}^{2+}$ and $\mathrm{Ca}^{2+}$ ions and eventually reducing soil permeability. The percent sodium in irrigation water is calculated using the equation:

$$
\% \mathrm{Na}=\frac{N a+K}{C a+M g+N a+K} \times 100
$$

The value of percentage sodium in the watershed is in the range of 3.55to 36.9 and 3.47 to 35.53 in the post- and pre-monsoon seasons respectively. The Table 5 shows that the majority of the water samples fall in excellent, good and permissible limits. One sample each during post and pre-monsoon season is classified as doubtful and unsuitable respectively.

\section{Residual Sodium Carbonate (RSC)}

Eaton (1950) developed the concept of residual sodium carbonate (RSC) for characterizing irrigation water quality concerning bicarbonate hazard. This is because irrigation water having a high concentration of bicarbonate, there is a tendency for calcium and magnesium to precipitate as carbonate. RSC in water can be calculated using the following equation.

$\mathrm{RSC}=\left(\mathrm{CO}_{3}+\mathrm{HCO}_{3}\right)-\left(\mathrm{Ca}^{2+}+\mathrm{Mg}^{2+}\right)$

The RSC value in the watershed varied from -2.08 to -0.13 and 0.04 to 1.23 during post and pre-monsoon seasons respectively. According to Wilcox (1958) classification, the entire water samples during post-monsoon seasons are suitable and are safe for irrigation. However, water samples of well no. 21 and 23 are doubtful and water in well no. 29 is unsuitable and the rest of the samples are suitable for irrigation during both the seasons. If bicarbonate rich water is used frequently for irrigation, it will severely affect soil permeability like the SAR and \% Na. 


\section{Permeability Index (PI)}

According to Doneen (1964), long-term use of water-rich in $\mathrm{Na}^{+}, \mathrm{Ca}^{2+}, \mathrm{Mg}^{2+}$ and $\mathrm{HCO}_{3}{ }^{-}$will affect soil permeability. As the permeability increases, suitability also increases. In Class I and Class II water types, maximum permeability will be $75 \%$. In class III, the maximum permeability will be $25 \%$. The class III type of water is unsuitable for irrigation. The permeability index of groundwater samples of the study area is calculated using the formula given below.

$\mathrm{PI}=\frac{\mathrm{Na}+\sqrt{\mathrm{HCO}_{3}}}{\mathrm{Ca} \mathrm{Mg} \mathrm{N} \mathrm{Na}} \times 100$

The computed permeability index values suggest that $18 \%$ and $20 \%$ and $82 \%$ and $80 \%$ of the samples are classified as Class-I and Class-II during the post- and pre-monsoon seasons (Fig. 6) and hence, the water is suitable for irrigation.

\section{Magnesium Hazard}

The magnesium hazard as developed by Paliwal (1972) says that if $\mathrm{MH}$ value is more than $50 \%$ will harm the crop yield as the soil becomes more alkaline. However, the $\mathrm{MH}$ values of groundwater samples are less than $50 \%$ in the study area and hence, they are suitable for irrigation.

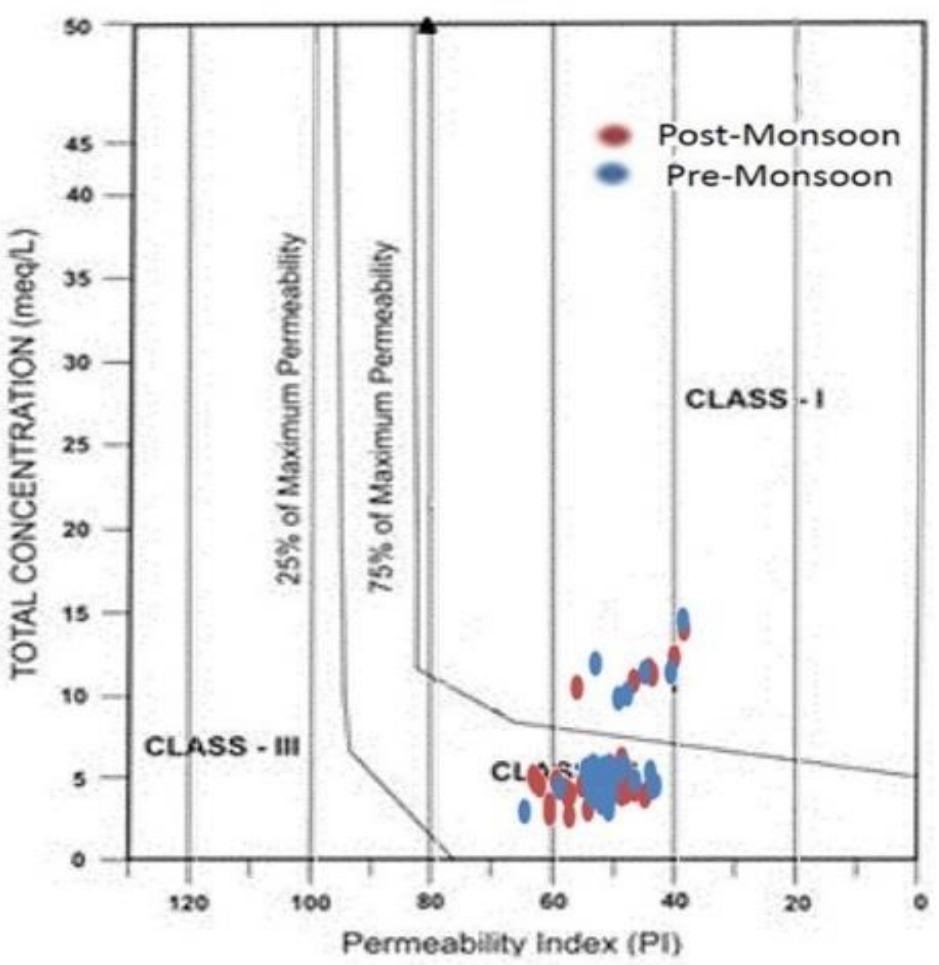

\section{USSL diagram}

Fig 6: Classification of Irrigation water based on permeability index

According to the FAO Land and Plant Nutrition Management Service, over 6\% of the world's land is affected by either salinity or sodicity. Salinity occurs through natural or human-induced processes that result in the accumulation of dissolved salt in the water to an extent that inhibits plant growth. Sodium chloride is the most abundant salt in water, which is released from weathering of parent rock containing soluble salts followed by calcium and magnesium chloride, high salt concentration result in the high osmotic potential of the soil solution, so the plant has to use more energy to absorb water and nutrient. The irrigation suitability of the groundwater in the watershed is made by plotting SAR Vs. EC in the USSL diagram (Fig 7).

According to the USSL diagram, the number of samples coming under the C1-S1 class during the post- and pre-monsoon season is $16 \%$ and $6 \%$ only. In C2-S1 class, $81 \%$ and $55 \%$ and in C3-S1class, 3\% and 39\% of the samples come under particular classes during the post- and pre-monsoon seasons. During the pre-monsoon season, $39 \%$ of the groundwater is not suitable for irrigation since they come under the class C3-S1. Because of higher salinity, they are classified as moderate water. Even if they are used, the yield from the respective sites will be less than the expected. From the results, it is clear that the salinity of the groundwater samples increases during pre-monsoon season due to the lowering of the water table, i.e. as the depth to water table increases, salinity also increases. 


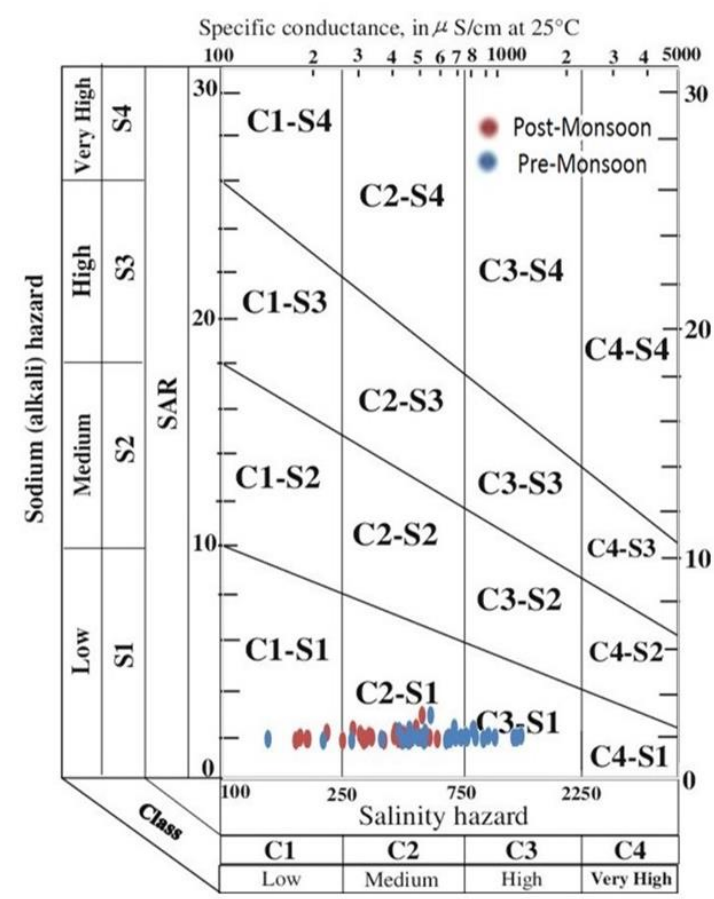

Piper diagram

Fig 7: USSL diagram for the classification of irrigation water (Richards 1954)

Graphical representation of relative abundance of cations and anions in the trilinear diagram (also known as Piper diagram) provides a convenient method to classify and infer hydro-geochemical facies based on the ion composition of the different water sample. In Piper diagram (Piper, 1944) a ternary diagram in the lower left represents cations $\left(\mathrm{Mg}^{2+}, \mathrm{Ca}^{2+} \mathrm{and} \mathrm{Na}^{+}+\mathrm{K}^{+}\right)$, a ternary diagram in the lower right represents anions $\left(\mathrm{Cl}^{-}, \mathrm{SO}_{4}{ }^{2+}\right.$ and $\left.\mathrm{HCO}_{3}{ }^{-}\right)$and a diamond plot in the middle, which is a matrix transformation of the two ternary diagrams, which indicate the type of groundwater. The relative concentration of ions in the watershed is plotted on the Piper trilinear diagram as represented in Fig 8.

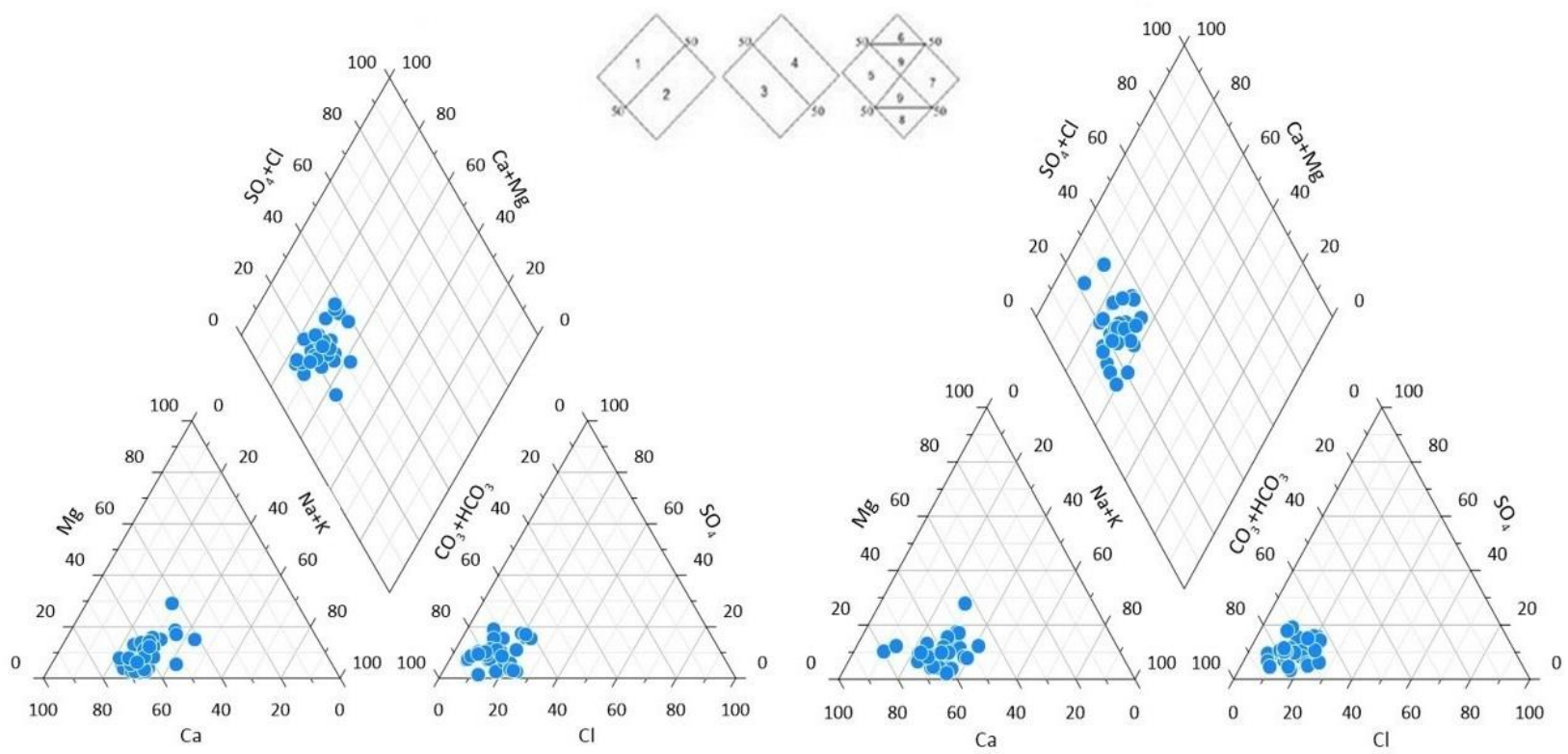

Fig 8: Piper's diagram shows dissolved ion for post- and pre-monsoon seasons

The ternary diagrams indicate that the water is dominated by calcium and bicarbonate in both seasons. In the diamond shape field, geochemical data fall in fields 1,3 and 5 in both seasons. The points in field 1 suggest the dominance of alkaline earth $\left(\mathrm{Ca}^{2+}+\mathrm{Mg}^{2+}\right)$ exceeds alkalies $\left(\mathrm{Na}^{+}+\mathrm{K}^{+}\right)$. The points in field 3 exhibit that dominance of $\mathrm{HCO}_{3}{ }^{-}$over $\mathrm{SO}_{4}{ }^{2+}$ and $\mathrm{Cl}^{-}$indicates weak acids $\left(\mathrm{CO}_{3}+\mathrm{HCO}_{3}{ }^{-}\right)$exceed strong acids $\left(\mathrm{SO}_{4}{ }^{2+}+\mathrm{Cl}^{-}\right)$and lastly points in field 5 indicate carbonate hardness (secondary alkalinity) exceed $50 \%$.

Further, Hounslow (1995) classified the piper diagram (diamond field) into four different Types as shown in Fig.9 based on the dominance of ions. 


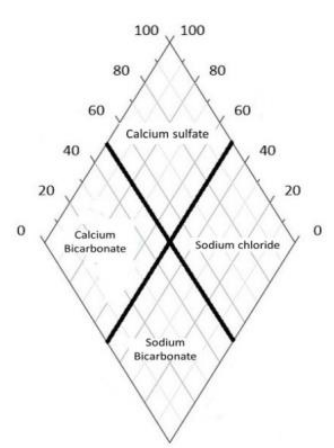
Type I - $\mathrm{Ca}^{2+}-\mathrm{Mg}^{2+}-\mathrm{Cl}^{-}-\mathrm{SO}_{4}{ }^{2+}$
Type II $-\mathrm{Na}^{+}-\mathrm{K}^{+}-\mathrm{Cl}^{-}-\mathrm{SO}_{4}{ }^{2+}$
Type III $-\mathrm{Na}^{+}-\mathrm{K}^{+}-\mathrm{Cl}^{-}-\mathrm{HCO}_{3}^{-}$
Type IV $-\mathrm{Ca}^{2+}-\mathrm{Mg}^{2+}-\mathrm{HCO}_{3}^{-}$

Fig 9: Classification of water according to Hounslow (1995)

According to Hounslow, the groundwater of the study area belongs to a Type IV, where $\mathrm{Ca}^{2+}-\mathrm{Mg}^{2+}-\mathrm{HCO}_{3}{ }^{-}$are dominant.

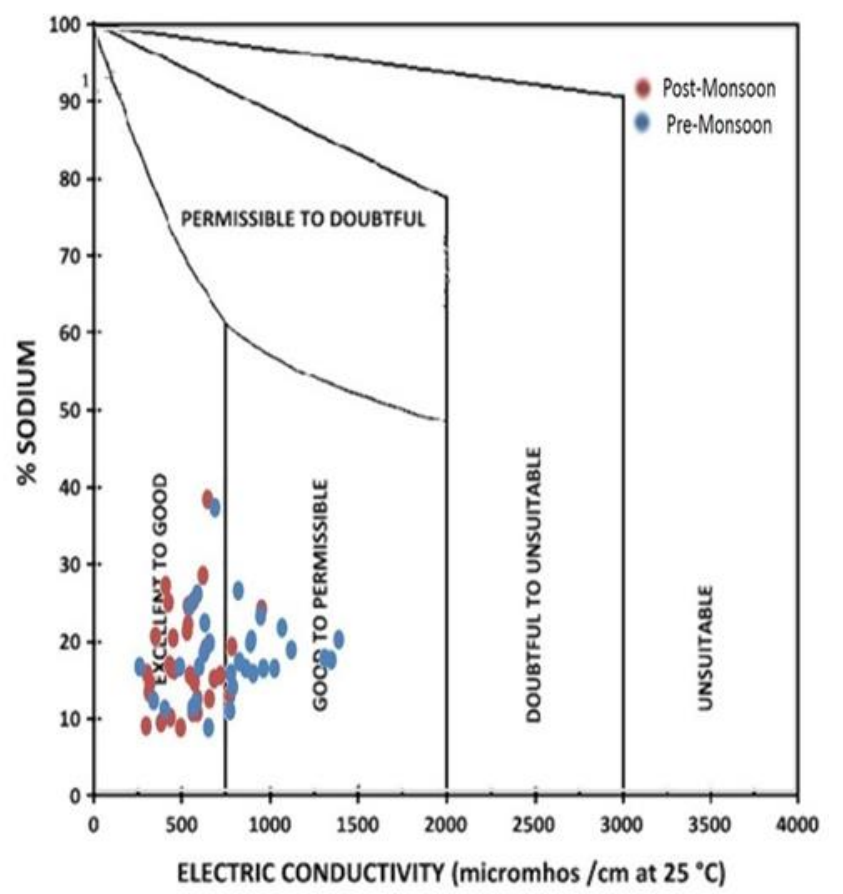

\section{Wilcox diagram}

Fig 10: Plot of percentage sodium versus electrical conductivity (Wilcox 1955)

Similar to the USSL diagram, the Wilcox diagram (Fig.10) is widely utilized for evaluating the suitability of water for agriculture. This diagram is prepared using the percent sodium and EC values. As mentioned earlier, high sodium irrigation, water leads to reduce permeability resulting in poor internal drainage. The plot on the Wilcox diagram shows that the water sample falls in the excellent to good, and good to permissible zones. In post-monsoon $97 \%$ fall in excellent to good and only $3 \%$ fall in the good to permissible zone. Whereas, in the pre-monsoon season, $61 \%$ fall in excellent to good, $39 \%$ in good to permissible zones.

\section{Conclusions}

In Kumadvati watershed, groundwater is the major source of water for domestic and irrigation activity. The groundwater sample collected during the post-monsoon season of 2018 and pre-monsoon season of 2019 is subject to physicochemical analysis, such as $\mathrm{pH}, \mathrm{EC}$, TDS, major cations and anions. The result suggests that the groundwater sample of post-monsoon indicates that the $\mathrm{pH}$ of the three samples is outside the range, i.e. they are acidic, but they are within the permissible limit during pre-monsoon season. The TDS value in some of the well during pre-monsoon season is beyond the desirable limit, but they are below the permissible limit but they are good during the post-monsoon season. The total hardness according to (Sawyer and MaCartly, 1967), $12 \%$ and $13 \%$ of the samples are very hard during the post- and pre-monsoon seasons. Hence, the consumption of very hard water should be restricted to a minimum. Other parameters are within the desirable or permissible limit for drinking purposes according to BIS standards. There is an increase in TH from post- to pre-monsoon season indicates that deterioration of groundwater during pre-monsoon season due to a decline in groundwater level.

The computed chemical parameter of groundwater concerning irrigation shows that $\mathrm{Ca}^{2+}$ is dominant cation and $\mathrm{HCO}_{3}{ }^{-}$among anions. Further, Piper plots also indicate $\mathrm{Ca}^{2+}-\mathrm{Mg}^{2+}-\mathrm{HCO}_{3}{ }^{-}$is the dominant hydrogeochemical facies in the watershed. Some of the groundwater samples are not suitable for irrigation purposes because of high salinity. Even in the case of RSC also, some of the well water samples, which are suitable during the post-monsoon season are not suitable in pre-monsoon and vice- versa. 


\section{ACKNOWLEDGEMENT:}

The authors gratefully acknowledge the facilities provided by the Chairman, Dept. of Applied Geology, Kuvempu University and the first author is thankful to Kuvempu University for the award of University fellowship for pursuing Ph.D. Degree program.

\section{REFERENCES}

Agrawal. V., and Jagetia, M. (1997). Hydrogeochemical assessment of ground water quality in Udaipur city, Rajasthan, India. In: Proceedings of national conference on "Dimensions of Environmental Stress in India", Department on Geology, M S.University, Baroda, India, pp 151-154

Ali, S. A., \& Ali, U. (2018). Hydrochemical characteristics and spatial analysis of groundwater quality in parts of Bundelkhand Massif, India. Applied water science, 8(1), 39.

3. Anbazhagan, S., and Nair, A. M. (2004). Geographic information system and groundwater quality mapping in Panvel Basin, Maharashtra, India. Environmental Geology, 45(6), 753-761.

4. APHA (1995). Standard methods for the examination of water and wastewater, 19th edn. American Public Health Association, Washington

5. BIS (2012). Drinking water specifications. Bureau of Indian Standards, IS:10500

6. CGWB (2010). Ground Water Quality in Shallow aquifers of India. Central Ground Water Board, Ministry of Water Resources, Government Of India, Faridabad, New Delhi.

7. Dasgupta, A.M., and Purohit, K.M. (2001). Status of surface and groundwater quality of Mandiakadar-Part II: agricultural utilities. Pollut Res 20(2):219-225

8. Doneen, L. D. (1964). Notes on water quality in Agriculture Published as a Water Science and Engineering Paper 4001. Department of Water Science and Engineering, University of California Eaton, F. M. (1950). Significance of carbonates in irrigation waters. Soil science, 69(2), 123-134.

Freeze, R. A., \& Cherry, J. A. (1979). Groundwater. Pretice-Hall. Inc., Englewood Cliffs, NJ.

Garg, V. K., Suthar, S., Singh, S., Sheoran, A., Jain, S. (2009). Drinking water quality in villages of southwestern Haryana, India: assessing human health risks associated with hydrochemistry. Environmental Geology, 58(6), 1329-1340.

Gibbs, R. J. (1970). Mechanisms controlling world water chemistry. Science, 17, 1088-1090.

Gupta, S., Mahato, A., Roy, P., Datta, J. K., Saha, R. N. (2008). Geochemistry of groundwater, Burdwan District, West Bengal, India. Environmental Geology, 53(6), 1271-1282.

14. Hart, B. T. (1974). A compilation of Australian Water Quality Criteria.
15. Hem, J. D. (1985). Study and interpretation of the chemical characteristics of natural water (Vol. 2254). Department of the Interior, US Geological Survey.

16. Hounslow, A. (1995). Water quality data: analysis and interpretation. CRC press.

17. Khurshid, S. H., Hasan, N., \& Zaheeruddin, M. (2002). Water quality status and environmental hazards in parts Environ Monit Assess of Yamuna-Karwan sub-basin of Aligarh-Mathura district, Uttar Predesh, India. J Appl Hydrol, 14(4), 30 -37. Paliwal K.V. (1972). Irrigation With Saline Water (p. 198) [Z]. Monogram No. 2 (New series). New Delhi: IARI

19. Piper, A. M. (1944). A graphic procedure in the geochemical interpretation of water-analyses. Eos, Transactions American Geophysical Union, 25(6), 914-928.

20. Rao, N. S. (2006). Seasonal variation of groundwater quality in a part of Guntur District, Andhra Pradesh, India. Environmental Geology, 49(3), 413-429.

21. Rao, N. S., Rao, G. S., Rao, S. V., Reddy, P. M., Devadas, D. J. (1999). Environmental control of groundwater quality in a tribal region of Andhra Pradesh, India. Indian Journal of Geology, 71(4), 299-304.

22. Richard, L. A. (1954). Diagnosis and improvement of saline and alkaline soil. USDA, Washington

23. Sadashivaiah, C. R. R. C., Ramakrishnaiah, C. R., Ranganna, G. (2008). Hydrochemical analysis and evaluation of groundwater quality in Tumkur Taluk, Karnataka State, India. International journal of environmental research and public health, 5(3), 158-164.

24. Sawyer, G. N., and McCartly, D. L. (1967). Chemistry of sanitary engineers, 2nd edn. McGraw-Hill, New York, pp 518

25. Sreedevi, P. D. (2004). Groundwater quality of Pageru river basin, Cuddapah district, Andhra Pradesh. J Geol Soc India, 64(5), 619-636.

26. Stumm, W., and Morgan, J. J. (1996). Aquatic chemistry. New York: Wiley. 1022 p.23

27. Subramanian, M. A., Aravamudan, G., \& Rao, G. S. (1983). Oxide pyrochlores-a review. Progress in Solid State Chemistry, $15(2), 55-143$

28. Wilcox, L. (1955). Classification and use of irrigation waters (No. 969). US Department of Agriculture.

29. Wilcox, L. V. (1958). Determining the quality of irrigation water (No. 197). US Department of Agriculture. 